\title{
Multiple neoplasms, single primaries, and patient survival
}

\author{
This article was published in the following Dove Press journal: \\ Cancer Management and Research \\ 5 March 2014 \\ Number of times this article has been viewed
}

\section{Magid H Amer}

Department of Medicine, St Rita's Medical Center, Lima, OH, USA
Correspondence: Magid H Amer St Rita's Medical Center, 825 West Market Street, Suite 203, Lima, $\mathrm{OH} 45805$, USA

Tel + I 6144990296

Fax + I 6I4 4484499

Email magidamer@email.com
Background: Multiple primary neoplasms in surviving cancer patients are relatively common, with an increasing incidence. Their impact on survival has not been clearly defined.

Methods: This was a retrospective review of clinical data for all consecutive patients with histologically confirmed cancer, with emphasis on single versus multiple primary neoplasms. Second primaries discovered at the workup of the index (first) primary were termed simultaneous, if discovered within 6 months of the index primary were called synchronous, and if discovered after 6 months were termed metachronous.

Results: Between 2005 and 2012, of 1,873 cancer patients, 322 developed second malignancies; these included two primaries $(n=284)$, and three or more primaries $(n=38)$. Forty-seven patients had synchronous primaries and 275 had metachronous primaries. Patients with multiple primaries were predominantly of Caucasian ancestry $(91.0 \%)$, with a tendency to develop thrombosis $(20.2 \%)$, had a strong family history of similar cancer $(22.3 \%)$, and usually presented with earlier stage 0 through stage II disease (78.9\%). When compared with 1,551 patients with a single primary, these figures were $8.9 \%, 15.6 \%, 18.3 \%$, and $50.9 \%$, respectively $(P \leq 0.001)$. Five-year survival rates were higher for metachronous cancers $(95 \%)$ than for synchronous primaries (59\%) and single primaries (59\%). The worst survival rate was for simultaneous concomitant multiple primaries, being a median of 1.9 years. The best survival was for patients with three or more primaries (median 10.9 years) and was similar to the expected survival for the age-matched and sex-matched general population $(P=0.06991)$.

Conclusion: Patients with multiple primaries are usually of Caucasian ancestry, have less aggressive malignancies, present at earlier stages, frequently have a strong family history of similar cancer, and their cancers tend to have indolent clinical behavior with longer survival rates, possibly related to genetic predisposition.

Keywords: genetic susceptibility, incidence study, hereditary, multiple primary neoplasms, survival analysis, prognosis

\section{Introduction}

Over the last three decades, there have been advances in the diagnostic techniques and treatment modalities available for cancer patients, which have led to earlier detection of cancer, improved disease management, and increased survival. Such improvement has caused a surge in the number of surviving patients with secondary multiple neoplasms, posing an additional threat in terms of morbidity and mortality. Such an entity of multiple neoplasms is not rare or new, being described by Billroth as far back as $1889 .{ }^{1}$ In 1932, Warren and Gates published the first study of 1,259 patients with multiple neoplasms. ${ }^{1}$ Ever since, there have been numerous reports addressing the occurrence of second primary neoplasms. Nowadays, it is accepted that the prevalence 
of multiple neoplasms varies between $0.7 \%$ and $11.7 \%$ in different populations ${ }^{1}$ and this number is increasing. ${ }^{2}$

Even though there is an adequate body of published data describing the epidemiology and clinical characteristics of patients with single and multiple primaries, there are few reports addressing patient survival with different results. ${ }^{3,4}$ In the present study, we attempt to determine the incidence of multiple primaries and possible risk factors, and to assess the impact of multiple neoplasms on patient survival.

\section{Materials and methods}

The medical records of cancer patients initially seen and/or closely followed by the author at a regional cancer center were retrospectively reviewed, with special emphasis on the incidence of secondary neoplasms, risk factors for multiple malignancies, and their impact on survival. The study included all consecutive adult patients with histologically confirmed malignancies, with the exception of nonmelanoma skin cancer and carcinoma in situ of the uterine cervix. All data collected were stripped of any patient identification in compliance with the Health Information Protection Act. The study was approved by the institutional review board at St Rita's Medical Center.

Patient age was estimated based on the date of initial histologic diagnosis of cancer. Elderly patients were defined as being aged $\geq 65$ years. Ethnic background was classified as Caucasian, Native American Indian (from both parents), African American, and others. Smoking status was expressed as nonsmoker or smoker. Body mass index (BMI, $\mathrm{kg} / \mathrm{m}^{2}$ ) was calculated and grouped into those who were underweight $\left(\mathrm{BMI}<18.4 \mathrm{~kg} / \mathrm{m}^{2}\right)$, normal weight $\left(18.5-24.9 \mathrm{~kg} / \mathrm{m}^{2}\right)$, overweight (25-29.9 kg/m²), obese (30-39.9 kg/m²), or morbidly obese (BMI $>40 \mathrm{~kg} / \mathrm{m}^{2}$ ). Multiple cancers were defined as two or more primary cancers occurring in an individual that are not an extension, recurrence, or metastasis. Based on the chronology of presentation, they were categorized according to Warren and Gates. ${ }^{5}$ An index tumor was defined as the first diagnosed malignant tumor in patients with multiple malignancies. Second primaries discovered at workup of the index primary were termed simultaneous; within 6 months of the index primary were called synchronous; and after 6 months, termed metachronous primaries. The latter were further defined as metachronous $<5$ years ( 6 months to 59 months after index primary) and metachronous $\geq 5$ years (an interval equal to or more than 5 years). Patients with simultaneous bilateral paired organ cancers such as breast, lung, or renal, were considered to have a single primary if their cancers had the same histologic diagnosis.
The primary tumor site was defined according to the International Classification of Diseases Tenth Revision (ICD-10) ${ }^{6}$ (http://apps.who.int/classifications/icd10/ browse/2010/en). Histologic diagnosis was classified into adenocarcinoma, whether duct cell type or lobular; squamous cell cancer; other types of cancer such as lymphoma or leukemia; and undetermined, such as undifferentiated malignancies or inadequately confirmed neoplasms. Stage of disease was defined according to the American Joint Committee of Cancer Staging Classification (Seventh Edition, 2010). Patients with leukemia were considered to have stage IV. Other cancer types for which there is no defined staging system were categorized as stage 0 if carcinoma in situ, stage I if localized, stage II if there was regional lymph node involvement, stage III if locally or regionally advanced, and stage IV if there was evidence of distant metastases. For patients with multiple malignancies, the date of the first primary diagnosis was considered as the date of initial diagnosis, and the most advanced stage of any simultaneous primaries was recorded as the stage of disease.

Patients were questioned about any previous history of thromboembolic events, and closely followed for such a possibility. Only patients with clinical manifestations and/ or radiologic evidence of thrombotic manifestations were considered to have had thromboembolic events. Family history of cancer was categorized as strong if one of the patient's first-degree relatives (biological parents, brothers, sisters, sons, or daughters) had a similar cancer site; intermediate if first-degree relatives had other cancer sites; and weak if only second-degree or third-degree relatives had cancer. The risk of a second primary was calculated as the number of patients with multiple primaries relative to the total number of cancer patients seen, according to tumor site and stage of disease.

Duration of follow-up was measured from the date of initial clinical examination until the last date seen for follow-up, and was expressed in months. The final status of the patient, whether alive or dead, was recorded. Time intervals between multiple primaries were calculated from the date of histologic diagnosis of the first/index primary to the second primary and in between subsequent primaries, and were measured in months. Overall survival was calculated from the date of initial histologic diagnosis of cancer until the date of death, or if the patient was confirmed to be alive by the end of December 2012, and was measured in years. Survival of patients was compared with that of an age-matched and sex-matched control group, based on life expectancy of the general population derived from the actuarial life table published by the US Social Security 
Administration, 2009 (http://www.ssa.gov/oact/STATS/ table4c6.html).

Differences between categorical groups were tested using Pearson's chi-squared test. Analysis of variance was used to analyze the differences between means of continuous variables, such as age in years, and expressed as the mean \pm standard deviation. The chi-squared test was used to examine the relationship between qualitative variables. Factors influencing survival were estimated by Kaplan-Meier survival analysis, and the log-rank test was used to compare the distribution of survival between groups. In all analyses, a two-sided $P$-value less than 0.05 was considered to be statistically significant. Missing data were deleted from the analysis. Statistical analysis was conducted using Statistica version 10 software (Stat Soft Inc, Tulsa, OK, USA).

\section{Results}

\section{Incidence of multiple primaries}

Between January 2005 and December 2012, of 1,873 consecutive cancer patients, 1,551 (82.8\%) had a single primary neoplasm and $322(17.2 \%)$ had multiple neoplasms. Patients with multiple primaries included $284(15.2 \%)$ patients with two primaries, $30(1.2 \%)$ with three, six $(0.3 \%)$ with four, and two $(0.1 \%)$ with five neoplasms. The mean interval between the index primary and the second primary was $117 \pm 124.0$ months, with a median of 76.5 months. Twenty-four (7.5\%) patients presented with their second primary within the first month (simultaneous primary), 23 (7.1\%) presented within the subsequent 5 months (synchronous), 88 (27.3\%) presented within 5 years (metachronous $<5$ years), and $78(24.2 \%)$ presented after 5 years (metachronous $\geq 5$ years). Demographic data on single versus multiple primaries are shown in Table 1. Clinical information, tumor characteristics, and survival data for cases with single versus synchronous and metachronous primaries are outlined in Tables 2 and 3 .

When analysis was limited to the 1,229 patients who were initially diagnosed with cancer during the interval between January 2005 and December 2012, 75 (6.1\%) had multiple primaries, including $69(5.6 \%)$ with two primaries and six $(0.5 \%)$ with three or more primaries. Thirty-eight (3.1\%) patients had synchronous primaries and 37 (3.1\%) had metachronous primaries.

The cumulative incidence of multiple primaries increased with increasing time from initial cancer diagnosis, reaching $7.2 \%$ at 5 years, $11.4 \%$ at 10 years, $13.3 \%$ at 15 years, $14.8 \%$ at 20 years, and $17.2 \%$ after 20 years. Proactive screening for a second primary during follow-up of cancer survivors led to detection of 24 (1.3\%) asymptomatic second primaries
Table I Demographic data on patients with single and multiple cancer primaries

\begin{tabular}{|c|c|c|c|c|}
\hline $\begin{array}{l}\text { Demographic } \\
\text { data }\end{array}$ & $\begin{array}{l}\text { All } \\
\text { patients } \\
\text { n (\%) }\end{array}$ & $\begin{array}{l}\text { Single } \\
\text { primary } \\
\text { n (\%) }\end{array}$ & $\begin{array}{l}\text { Multiple } \\
\text { primaries } \\
\text { n (\%) }\end{array}$ & $P$-value \\
\hline Patients (n) & 1,873 & $|, 55|$ & 322 & \\
\hline \multicolumn{5}{|l|}{ Age at diagnosis } \\
\hline Mean \pm SD & $61.1 \pm 14.5$ & $61.3 \pm 14.4$ & $60.2 \pm 15.2$ & 0.19611 \\
\hline$\leq 64$ years & I,064 (56.8) & $889(57.3)$ & 175 (54.4) & 0.32754 \\
\hline$\geq 65$ years & 809 (43.2) & 662 (42.7) & I 47 (45.7) & \\
\hline \multicolumn{5}{|l|}{ Sex } \\
\hline Male & 728 (38.9) & $581(37.5)$ & I 47 (45.7) & 0.00606 \\
\hline Female & $\mathrm{I}, 145(61.1)$ & $970(62.5)$ & $175(54.4)$ & \\
\hline \multicolumn{5}{|l|}{ Ethnicity } \\
\hline Caucasian & I,48I (82.7) & I, $197(80.9)$ & $284(91.0)$ & 0.00007 \\
\hline African & $232(13.0)$ & $216(14.6)$ & $16(5.1)$ & \\
\hline \multicolumn{5}{|l|}{ American } \\
\hline Native & $43(2.4)$ & $35(2.4)$ & $8(2.6)$ & \\
\hline \multicolumn{5}{|l|}{ American Indian } \\
\hline Others & $35(2.0)$ & $31(2.1)$ & $4(1.3)$ & \\
\hline \multicolumn{5}{|l|}{ BMI } \\
\hline Underweight & $69(4.4)$ & $53(4.1)$ & $16(5.9)$ & 0.01406 \\
\hline Normal BMI & $482(30.6)$ & $393(30.2)$ & $89(32.7)$ & \\
\hline Overweight & $498(31.6)$ & $398(30.5)$ & $100(36.8)$ & \\
\hline Obese & 417 (26.5) & 364 (27.9) & $53(19.5)$ & \\
\hline Morbid obesity & $109(6.9)$ & $95(7.3)$ & $14(5.2)$ & \\
\hline \multicolumn{5}{|l|}{ Atherosclerosis } \\
\hline Absent & I, I 79 (62.9) & I,005 (64.8) & $174(54.0)$ & 0.00027 \\
\hline Present & $694(37.1)$ & $546(35.2)$ & $148(46.0)$ & \\
\hline \multicolumn{5}{|l|}{ Smoking } \\
\hline Nonsmoker & 737 (4I.5) & $633(43.1)$ & $104(33.8)$ & 0.00253 \\
\hline Smoker & I,040 (58.5) & $836(56.9)$ & $204(66.2)$ & \\
\hline \multicolumn{5}{|l|}{ Thrombosis } \\
\hline None & I,566 (83.6) & I,309 (84.4) & 257 (79.8) & 0.04320 \\
\hline Thrombosis & $307(16.4)$ & $242(15.6)$ & $65(20.2)$ & \\
\hline \multicolumn{5}{|l|}{$\mathrm{FH}$ of cancer } \\
\hline None & $239(16.6)$ & $203(16.9)$ & $36(15.1)$ & 0.00928 \\
\hline Weak FH & $193(13.4)$ & $176(14.7)$ & $17(7.1)$ & \\
\hline Intermediate $\mathrm{FH}$ & $733(51.0)$ & $601(50.1)$ & $132(55.5)$ & \\
\hline Strong FH & $273(19.0)$ & $220(18.3)$ & $53(22.3)$ & \\
\hline \multicolumn{5}{|l|}{ Initial primary site } \\
\hline Breast & $657(35.1)$ & $563(36.3)$ & $94(29.2)$ & 0.0000 \\
\hline Lung & $232(12.4)$ & $219(14.1)$ & $13(4.0)$ & \\
\hline Genitourinary & $193(10.3)$ & $119(7.7)$ & $74(23.0)$ & \\
\hline Gastrointestinal & 167 (8.9) & I 38 (8.9) & $29(9.0)$ & \\
\hline Hematologic & $130(6.9)$ & $115(7.4)$ & $15(4.7)$ & \\
\hline Gynecologic & $124(6.6)$ & $83(5.4)$ & $4 \mathrm{I}(12.7)$ & \\
\hline Lymphoma & $120(6.4)$ & $100(6.5)$ & $20(6.2)$ & \\
\hline Head and neck & $79(4.2)$ & $68(4.4)$ & II (3.4) & \\
\hline Hepatobiliary & $52(2.8)$ & $52(3.4)$ & 0 & \\
\hline Dermatologic & $5 \mathrm{I}(2.7)$ & $32(2.1)$ & $19(5.9)$ & \\
\hline Others & $68(3.6)$ & $62(4.0)$ & $6(1.9)$ & \\
\hline \multicolumn{5}{|l|}{ Initial cancer stage } \\
\hline Stage 0 & $53(2.8)$ & $4 \mid(2.6)$ & $12(3.7)$ & 0.0000 \\
\hline Stage I & $476(25.4)$ & $336(21.7)$ & 140 (43.5) & \\
\hline Stage II & $515(27.5)$ & $413(26.6)$ & $102(31.7)$ & \\
\hline Stage III & 369 (19.7) & $333(21.5)$ & $36(11.2)$ & \\
\hline Stage IV & $460(24.6)$ & $428(27.6)$ & $32(9.9)$ & \\
\hline
\end{tabular}

(Continued) 
Table I (Continued)

\begin{tabular}{|c|c|c|c|c|}
\hline $\begin{array}{l}\text { Demographic } \\
\text { data }\end{array}$ & $\begin{array}{l}\text { All } \\
\text { patients } \\
\text { n (\%) }\end{array}$ & $\begin{array}{l}\text { Single } \\
\text { primary } \\
\text { n (\%) }\end{array}$ & $\begin{array}{l}\text { Multiple } \\
\text { primaries } \\
\text { n (\%) }\end{array}$ & $P$-value \\
\hline \multicolumn{5}{|l|}{ Present status } \\
\hline Alive & $977(52.2)$ & $850(54.8)$ & $127(39.4)$ & 0.00000 \\
\hline Died & $896(47.8)$ & $701(45.2)$ & $195(60.6)$ & \\
\hline \multicolumn{5}{|c|}{ Survival from diagnosis, years } \\
\hline Mean \pm SD & $6.5 \pm 7.6$ & $5.0 \pm 5.7$ & $13.8 \pm 10.96$ & 0.00000 \\
\hline Median & 3.39 & 3.5 & 10.9 & \\
\hline Range & $0-62.7$ & $0-62.7$ & $0.1-5 \mid .7$ & \\
\hline At 5 years & $66 \%$ & $59 \%$ & $92 \%$ & 0.0000 \\
\hline At 10 years & $39 \%$ & $27 \%$ & $80 \%$ & \\
\hline At 15 years & $27 \%$ & $15 \%$ & $66 \%$ & \\
\hline At 20 years & $19 \%$ & $9 \%$ & $55 \%$ & \\
\hline At 30 years & $13 \%$ & $4 \%$ & $40 \%$ & \\
\hline
\end{tabular}

Note: $P$, statistical differences between single primary and multiple primaries. Abbreviations: BMI, body mass index; FH, family history of cancer; SD, standard deviation.

at stage 0 (carcinoma in situ), mainly following routine mammography $(n=4)$, plasmapheresis for elevated serum globulin ( $n=8)$, screening colonoscopy $(n=2)$, flow cytometry for incidental lymphocytosis $(n=7)$, digital rectal examination of the prostate $(n=1)$, and skin examination for melanoma detection $(n=2)$. Apart from those with breast cancer, these patients were treated less aggressively with local excision or just close observation.

\section{Clinical presentation}

When single and multiple primaries were compared, patients with a single primary were predominantly women, less likely to be smokers, had a lower prevalence of atherosclerosis, and showed a higher tendency for obesity. Their tumors were predominantly of adenocarcinoma cell type (945 patients, $60.9 \%$ ), were more likely to be breast or lung primaries, and predominantly of advanced stage III or IV disease. Conversely, patients with multiple primaries were predominantly of Caucasian ancestry, had a tendency to be a smoker and have atherosclerosis, frequently developed vascular thrombosis, and had a strong family history of cancer. They usually developed generalized multicentric malignancies (150 cases, $48.2 \%$ ), were more likely to present with genitourinary, gynecologic, colorectal, or dermatologic primaries, and were predominantly at earlier stage 0 through stage II disease (Table 1). Subsequent primaries comprised fewer breast and prostate cancers but more lung and colorectal cancers, and were predominantly at an advanced stage of disease compared with the index primaries (Table 4).

When synchronous and metachronous primaries were compared, patients with metachronous primaries were usually women; younger in age; with a higher tendency to develop vascular thrombosis, especially arterial; had breast, prostate, or colorectal primaries; and usually presented at earlier stage 0 through stage II disease.

The most common initial primary neoplasms in cancer survivors with multiple primaries were breast (29\%), prostate (14.9\%), and colorectal $(9.0 \%)$ sites. For the subsequent second primary, the most common were breast (18.3\%), lung (18.0\%), colorectal (11.5\%), and prostate (6.5\%). Incidentally, none of the 34 patients with pancreatic, hepatocellular, gallbladder, or biliary cancer and only one of 28 patients with acute leukemia lived long enough to present with a second malignancy (Table 4). Patients with multiple primaries who were smokers $(n=204)$ were more likely to present initially with prostate $(18.1 \%)$, colorectal $(9.8 \%)$, bladder $(6.9 \%)$, or lung $(5.9 \%)$ primaries compared with nonsmokers $(\mathrm{n}=104$; $8.7 \%, 8.7 \%, 1.9 \%$, and $0.9 \%$, respectively, $P=0.00183$ ). A strong family history was particularly noticed in patients initially presenting with breast $(26.9 \%)$, prostate $(26.7 \%)$, colorectal $(25.3 \%)$, laryngeal $(25.0 \%)$, lung $(20.9 \%)$, or urinary bladder $(20 \%)$ cancers, as well as in patients with multiple primaries (22.3\%, Tables 1 and 2). When all patients of Caucasian ancestry were compared with other ethnic groups, there was a preponderance of male sex, age over 65 years, normal BMI or underweight, atherosclerosis, vascular thrombosis, multiple thrombophilic gene mutations, a family history of cancer, and frequent multiple primaries $(P<0.05)$, but no differences in regards to smoking patterns (Table 5).

All patients were closely followed for a mean duration of $25.0 \pm 23.8$ months. At the end of the study, nearly half (48\%) of them had died, predominantly from progressive malignancy.

\section{Possible risk factors for multiple primaries}

Patients initially presenting with thyroid, urinary bladder, prostate, cervical, and uterine cancers were more liable to develop a second malignancy, while those with hepatic, biliary, and pancreatic cancers, as well as those with acute leukemia, rarely developed second primaries (Table 4). This is much more noticeable in cases with earlier stage 0 through stage II cancers compared with advanced stage III and stage IV malignancies (Table 4), and may be related to the poor outcome for these patients, who do not survive long enough for development of a second primary.

\section{Impact on survival}

Overall, patients with multiple primaries had better survival than those with a single primary (Table 1 and Figure 1). 
Table 2 Clinical presentation of cancer patients with a single primary compared with synchronous and metachronous multiple primaries

\begin{tabular}{|c|c|c|c|c|}
\hline Demographic data & $\begin{array}{l}\text { Single } \\
\text { primary } \\
\text { n (\%) }\end{array}$ & $\begin{array}{l}\text { Synchronous } \\
\text { primaries } \\
\text { n (\%) }\end{array}$ & $\begin{array}{l}\text { Metachronous } \\
\text { primaries } \\
\text { n (\%) }\end{array}$ & $P$-value \\
\hline Patients (n) & $|, 55|$ & 47 & 275 & \\
\hline \multicolumn{5}{|l|}{ Age at diagnosis } \\
\hline$\leq 64$ years & $889(57.3)$ & $12(25.5)$ & $163(59.3)$ & 0.00006 \\
\hline$\geq 65$ years & $662(42.7)$ & $35(74.5)$ & $112(40.7)$ & \\
\hline \multicolumn{5}{|l|}{ Sex } \\
\hline Men & 581 (37.5) & $30(63.8)$ & $117(42.6)$ & 0.00050 \\
\hline Women & $970(62.5)$ & $17(36.2)$ & I $58(57.5)$ & \\
\hline \multicolumn{5}{|l|}{ Ethnicity } \\
\hline Caucasian & I, I 97 (80.9) & $4 \mathrm{I}(93.2)$ & $243(90.7)$ & 0.00013 \\
\hline African American & $216(14.6)$ & 0 & $16(6.0)$ & \\
\hline Native American Indian & $35(2.4)$ & $3(6.8)$ & $5(1.9)$ & \\
\hline Others & $3 I(2.1)$ & 0 & $4(1.5)$ & \\
\hline \multicolumn{5}{|l|}{$\mathrm{BMI}$} \\
\hline Underweight & $53(4.1)$ & $2(5.4)$ & $14(6.0)$ & 0.49852 \\
\hline Normal BMI & $393(30.2)$ & $14(37.8)$ & 75 (31.9) & \\
\hline Overweight & $857(65.8)$ & $21(56.8)$ & $146(62.1)$ & \\
\hline \multicolumn{5}{|l|}{ Atherosclerosis } \\
\hline Absent & I,005 (64.8) & $33(70.2)$ & $|4|(5 \mid .3)$ & 0.00006 \\
\hline Present & $546(35.2)$ & $14(29.8)$ & I 34 (48.7) & \\
\hline \multicolumn{5}{|l|}{ Smoking } \\
\hline Nonsmoker & $633(43.1)$ & $13(27.7)$ & 91 (34.9) & 0.00683 \\
\hline Smoker & $836(56.9)$ & $34(72.3)$ & $170(65.1)$ & \\
\hline \multicolumn{5}{|l|}{ Thrombosis } \\
\hline None & I,309 (84.4) & $40(85.1)$ & $217(78.9)$ & 0.02239 \\
\hline DVT & $77(5.0)$ & $2(4.3)$ & $22(8.0)$ & \\
\hline PE & $31(2.0)$ & $2(4.3)$ & $3(I . I)$ & \\
\hline $\mathrm{DVT}+\mathrm{PE}$ & $55(3.6)$ & $3(6.4)$ & II (4.0) & \\
\hline Catheter-related & $23(1.5)$ & 0 & $4(1.5)$ & \\
\hline Superficial phlebitis & $18(1.2)$ & 0 & I $(0.4)$ & \\
\hline Visceral clots & $13(0.8)$ & 0 & $9(3.3)$ & \\
\hline Arterial thrombosis & $25(1.6)$ & 0 & $8(2.9)$ & \\
\hline \multicolumn{5}{|l|}{$\mathrm{FH}$ of cancer } \\
\hline None & $203(16.9)$ & $3(9.7)$ & $33(15.9)$ & 0.04274 \\
\hline Weak FH & $176(14.7)$ & $2(6.5)$ & $15(7.3)$ & \\
\hline Intermediate $\mathrm{FH}$ & $601(50.1)$ & $17(54.8)$ & II 5 (55.6) & \\
\hline Strong FH & $220(18.3)$ & $9(29.0)$ & $44(21.3)$ & \\
\hline \multicolumn{5}{|l|}{ Present status } \\
\hline Alive & $850(54.8)$ & $19(40.4)$ & $108(39.3)$ & 0.00000 \\
\hline Died & $701(45.2)$ & $28(59.6)$ & $167(60.7)$ & \\
\hline \multicolumn{5}{|l|}{ Disease status } \\
\hline Cancer-free & $747(48.2)$ & $16(34.0)$ & $102(37.1)$ & 0.00075 \\
\hline With cancer & $804(51.8)$ & $31(66.0)$ & $173(62.9)$ & \\
\hline \multicolumn{5}{|l|}{ Causes of death } \\
\hline Cancer progression & $578(82.5)$ & $25(89.3)$ & I $42(85.0)$ & 0.81122 \\
\hline Therapy-related & $20(2.9)$ & I (3.6) & I (0.6) & \\
\hline Age-related & $54(7.7)$ & I (3.6) & $13(7.8)$ & \\
\hline Other causes & $37(5.3)$ & I (3.6) & $8(4.8)$ & \\
\hline Undetermined & $12(1.7)$ & 0 & $3(1.8)$ & \\
\hline \multicolumn{5}{|c|}{ Survival from diagnosis, years } \\
\hline Mean \pm SD & $5.0 \pm 5.7$ & $3.8 \pm 4.1$ & $15.5 \pm 10.85$ & 0.0000 \\
\hline Median & 3.5 & 2.35 & 12.46 & 0.0000 \\
\hline Range & $0-62.7$ & $0.1-17.8$ & $1.0-5 \mid .7$ & \\
\hline
\end{tabular}


Table 2 (Continued)

\begin{tabular}{|c|c|c|c|c|}
\hline Demographic data & $\begin{array}{l}\text { Single } \\
\text { primary } \\
\text { n (\%) }\end{array}$ & $\begin{array}{l}\text { Synchronous } \\
\text { primaries } \\
\text { n (\%) }\end{array}$ & $\begin{array}{l}\text { Metachronous } \\
\text { primaries } \\
\text { n (\%) }\end{array}$ & $P$-value \\
\hline At 5 years & $59 \%$ & $59 \%$ & $95 \%$ & 0.0000 \\
\hline At 10 years & $27 \%$ & $33 \%$ & $84 \%$ & \\
\hline At 20 years & $9 \%$ & $0 \%$ & $59 \%$ & \\
\hline \multicolumn{5}{|l|}{ Matched control } \\
\hline Mean \pm SD & $23.4 \pm 11.7$ & $\mid 5.9 \pm 8.1$ & $25.6 \pm 13.03$ & 0.02017 \\
\hline Median & 21.8 & 14.7 & 22.6 & 0.00021 \\
\hline Range & $3.2-66.4$ & $4.3-47.0$ & $5.0-66.4$ & \\
\hline
\end{tabular}

Note: $P$, statistical differences between single, synchronous, and metachronous primaries.

Abbreviations: BMI, body mass index; DVT, deep vein thrombosis; FH, family history of cancer; SD, standard deviation; PE, pulmonary embolism.

The best survival was for patients with three or more primaries, and was relatively similar to the projected life expectancy of the age-matched and sex-matched US population. This is in marked contrast with patients having a single primary (Figure 2). The worst survival was for synchronous primaries and single primaries, compared with metachronous primaries, especially if $>5$ years (Table 2 and Figure 3 ). However, there were no significant differences in survival between single, simultaneous, and synchronous primaries (Figure 3). This survival advantage for patients with multiple primaries persisted even if the analysis was limited to patients with invasive cancer by excluding all 53 patients initially presenting with carcinoma in situ (stage $0, P=0.0000$, Figure 4 ) or the study was limited to a specific interval of initial cancer diagnosis, such as patients initially diagnosed as having cancer between 2005 and 2012 ( $P=0.00236$, Figure 5). Further, there was no difference in survival between single and multiple primaries when survival with multiple primaries was calculated from the date of diagnosis of the second primary rather than from the date of the initial cancer diagnosis $(P=0.05956$, Figure 6$)$. Both single and metachronous primaries fared worse compared with the control group representing the life expectancy of the US population (Figure 7).

\section{Discussion}

\section{Incidence of multiple primaries}

Cancer survivors have a $14 \%$ increased risk of developing a second cancer primary compared with the general population. ${ }^{3,7,8}$ In the USA, the number of cancer survivors has tripled since 1971 and is growing by $2 \%$ each year. ${ }^{9}$ As a consequence, the number of cancer survivors presenting with multiple primaries has increased over time. Multiple primaries now account for $16 \%$ of the newly diagnosed malignancies reported in the US National Cancer Institute's Surveillance, Epidemiology, and End Results (SEER) program., ${ }^{910}$
The overall incidence of multiple primary neoplasms among cancer survivors varies widely in the literature from $1 \%$ to $37 \%$, depending on the type of analysis used, timing of data collection, and ethnicity of the subjects studied. In the USA, the incidence has varied from 3.5\% in New Mexico's triethnic population (1977), ${ }^{11}$ to $5.3 \%$ in an autopsy series (1968), ${ }^{12}$ to $8 \%$ according to SEER data (1975-2001). ${ }^{2}$ In Western Europe, multiple primaries accounted for $0.7 \%$ in a hospital registry in Scotland (1972), ${ }^{13} 6.3 \%$ in multiple European cancer registries (1995-1999), ${ }^{14}$ and $11.7 \%$ in an autopsy series from Sweden (1969). ${ }^{15}$ In the present study, the incidence of multiple primaries was $6.1 \%$ for patients initially diagnosed between 2005 and 2012.

The numbers and types of multiple primaries relative to the total number of cancer patients also varies in the literature. The incidence of three or more primaries varied from $0.2 \%$ in a cancer center in Jordan (2006-2011), ${ }^{16} 1.1 \%$ in an autopsy series from Japan (1962-1981), ${ }^{17} 2.0 \%$ in a cancer center in France (1980-2009), ${ }^{10}$ to $0.5 \%$ in the present study (2005-2012). Metachronous primaries accounted for $1.0 \%$ in an autopsy study from the USA (1982), ${ }^{18} 5.3 \%$ in a study from Switzerland (1975-1983), ${ }^{19}$ and 3.1\% in the present study (2005-2012).

The incidence of multiple primary cancers has recently increased. During 1995-2008, the percentage of multiple primary cancers at all sites increased in the USA by $25.4 \%$ using SEER rules (from $14.6 \%$ to $18.4 \%$ ). ${ }^{20}$ In Finland, the risk of second malignancies increased by $50 \%$ between the 1950s and the 1980s..$^{21,22}$ The cumulative incidence of multiple primaries also increases with increasing time since initial primary diagnosis. ${ }^{23}$ In the present study, the cumulative incidence of second primaries for all cancer patients has increased from $7.2 \%$ at 5 years to $17.2 \%$ after 20 years. It has been suggested that, in patients with familial cancer syndrome, the risk of a second primary is approximately $3 \%$ for 
Table 3 Tumor characteristics of cancer patients with a single primary compared with those having synchronous and metachronous multiple primaries

\begin{tabular}{|c|c|c|c|c|}
\hline Tumor characteristics & $\begin{array}{l}\text { Single } \\
\text { primary } \\
\text { n (\%) }\end{array}$ & $\begin{array}{l}\text { Synchronous } \\
\text { primaries } \\
\text { n (\%) }\end{array}$ & $\begin{array}{l}\text { Metachronous } \\
\text { primaries } \\
\text { n (\%) }\end{array}$ & $P$-value \\
\hline Patients (n) & $|, 55|$ & 47 & 275 & \\
\hline \multicolumn{5}{|l|}{ Primary site } \\
\hline Breast (C50) & $563(36.3)$ & $6(12.8)$ & $88(32.0)$ & 0.0000 \\
\hline Lung (C33-34, C45) & $219(14.1)$ & $6(12.8)$ & $7(2.6)$ & \\
\hline Oral-pharynx (C00-I3) & $34(2.2)$ & 0 & $4(1.5)$ & \\
\hline Larynx (C32) & $7(0.5)$ & $I(2.1)$ & $3(1.1)$ & \\
\hline Esophagus (CI5) & $28(1.8)$ & $I(2.1)$ & I (0.4) & \\
\hline Colorectal (CI8-20) & $|2|(7.8)$ & $4(8.5)$ & $25(9.1)$ & \\
\hline Renal (C64-65) & $27(1.7)$ & $I(2.1)$ & $5(1.8)$ & \\
\hline Bladder (C67) & $17(1.1)$ & $6(12.8)$ & II (4.0) & \\
\hline Prostate (C6I) & $62(4.0)$ & $5(10.6)$ & $43(15.6)$ & \\
\hline Ovary (C56) & $33(2.1)$ & $3(6.4)$ & $5(1.8)$ & \\
\hline Uterus (C54) & $20(1.3)$ & 0 & $14(5.1)$ & \\
\hline Cervix (C53) & $24(1.6)$ & 0 & $18(6.6)$ & \\
\hline Liver (C22) & $9(0.6)$ & 0 & 0 & \\
\hline Biliary (C23-24) & $9(0.6)$ & 0 & 0 & \\
\hline Pancreas (C25) & $34(2.2)$ & 0 & 0 & \\
\hline Melanoma (C43) & $27(1.7)$ & $2(4.3)$ & $14(5.1)$ & \\
\hline Thyroid (C73) & $3(0.2)$ & $I(2.1)$ & $2(0.7)$ & \\
\hline Acute leukemia (C9I) & $28(1.8)$ & I $(2.1)$ & 0 & \\
\hline CLL (C9I) & $45(2.9)$ & $3(6.4)$ & $6(2.2)$ & \\
\hline Lymphoma (C77) & $100(6.5)$ & $3(6.4)$ & $17(6.2)$ & \\
\hline Myeloma (C90) & $36(2.3)$ & $I(2.1)$ & $2(0.7)$ & \\
\hline Others & $105(6.8)$ & $3(6.4)$ & $10(3.6)$ & \\
\hline \multicolumn{5}{|l|}{ Pathologic diagnosis } \\
\hline Adenocarcinoma & $432(27.9)$ & $19(40.4)$ & $65(23.6)$ & 0.0000 \\
\hline Duct cell cancer & $478(30.8)$ & $5(10.6)$ & $58(21.1)$ & \\
\hline Lobular cancer & $35(2.3)$ & 0 & $4(1.5)$ & \\
\hline Squamous cell carcinoma & $130(8.4)$ & $7(14.9)$ & II (4.0) & \\
\hline Other types & 371 (23.9) & $12(25.5)$ & $50(18.2)$ & \\
\hline Undetermined & $105(6.8)$ & $4(8.5)$ & $87(31.6)$ & \\
\hline \multicolumn{5}{|l|}{ Cancer laterality } \\
\hline Left side & $465(30.7)$ & $9(19.6)$ & $73(27.6)$ & 0.00016 \\
\hline Right side & $476(31.4)$ & II (23.9) & $56(21.1)$ & \\
\hline Bilateral & $67(4.4)$ & $2(4.4)$ & $10(3.8)$ & \\
\hline No laterality & $509(33.6)$ & $24(52.2)$ & $126(47.6)$ & \\
\hline \multicolumn{5}{|l|}{ Multicentricity } \\
\hline Unifocal cancer & $\mathrm{I}, 076(75.0)$ & $32(69.6)$ & $211(87.9)$ & 0.00003 \\
\hline Multifocal cancer & $369(25.0)$ & $14(30.4)$ & $29(12.1)$ & \\
\hline \multicolumn{5}{|l|}{ Cancer stage } \\
\hline Stage 0 & $4 \mid(2.6)$ & I (2.I) & II (4.0) & 0.0000 \\
\hline Stage I & $336(21.7)$ & II (23.4) & $129(46.9)$ & \\
\hline Stage II & $413(26.6)$ & $8(17.0)$ & $94(34.2)$ & \\
\hline Stage III & $333(21.5)$ & II (23.4) & $25(9.1)$ & \\
\hline Stage IV & $428(27.6)$ & $16(34.0)$ & $16(5.8)$ & \\
\hline
\end{tabular}

Notes: $P$, statistical differences between single, synchronous, and metachronous primaries. Primary site (International Classification of Disease code site) (ICD-I0 Site). Abbreviation: CLL, chronic lymphocytic leukemia.

each year of survival after the first cancer occurrence. When the figure is projected over an 18-year span of survival, the cumulative risk of a second primary exceeds $40 \%{ }^{24}$ More than one quarter (28\%) of the population surviving childhood cancer experienced additional cancer primaries, and within
20 years from diagnosis of the index primary, the estimated cumulative incidence of multiple primaries was reported to reach $47 \%{ }^{23}$

The higher incidence of multiple primaries among all cancer patients reported in this study as well as in other 
Table 4 Risk of developing multiple primaries in cancer patients relative to initial primary site and initial cancer staging

\begin{tabular}{|c|c|c|c|c|c|c|c|c|}
\hline & \multirow{2}{*}{$\begin{array}{l}\text { Risk of } \\
\text { multiple } \\
\text { primaries (\%) }\end{array}$} & \multirow{2}{*}{$\begin{array}{l}\text { Single } \\
\text { primary } \\
\text { n (\%) }\end{array}$} & \multicolumn{6}{|c|}{ Multiple primaries } \\
\hline & & & $\begin{array}{l}\text { Index } \\
\text { primary } \\
\text { n (\%) }\end{array}$ & $\begin{array}{l}\text { Second } \\
\text { primary } \\
\text { n (\%) }\end{array}$ & $\begin{array}{l}\text { Third } \\
\text { primary } \\
\text { n (\%) }\end{array}$ & $\begin{array}{l}\text { Fourth } \\
\text { primary } \\
\text { n (\%) }\end{array}$ & $\begin{array}{l}\text { Fifth } \\
\text { primary } \\
\text { n (\%) }\end{array}$ & $\begin{array}{l}\text { Total } \\
\text { n (\%) }\end{array}$ \\
\hline \multicolumn{9}{|l|}{ Primary site } \\
\hline Patients (n) & & $|, 55|$ & 322 & 322 & 38 & 8 & 2 & 692 \\
\hline Thyroid & 50.0 & $3(0.2)$ & $3(0.9)$ & $5(1.6)$ & $2(5.3)$ & 0 & 0 & $10(1.4)$ \\
\hline Bladder & 50.0 & $17(1.1)$ & $17(5.3)$ & $5(1.6)$ & I (2.6) & I (I2.5) & 0 & $24(3.5)$ \\
\hline Prostate & 43.6 & $62(4.0)$ & $48(14.9)$ & $21(6.5)$ & I (2.6) & I (I2.5) & 0 & 7I (I0.3) \\
\hline Cervix & 42.9 & $24(1.6)$ & $18(5.6)$ & $2(0.6)$ & 0 & 0 & 0 & $20(2.9)$ \\
\hline Uterus & 41.2 & $20(1.3)$ & $14(4.4)$ & $4(1.2)$ & I (2.6) & 0 & 0 & $19(2.7)$ \\
\hline Melanoma & 37.2 & $27(1.7)$ & $16(5.0)$ & $7(2.2)$ & $3(7.9)$ & $\mathrm{I}(\mathrm{I} 2.5)$ & 0 & $27(3.9)$ \\
\hline Larynx & 36.4 & $7(0.5)$ & $4(1.2)$ & I $(0.3)$ & 0 & 0 & 0 & $5(0.7)$ \\
\hline Ovary & 19.5 & $33(2.1)$ & $8(2.5)$ & II (3.4) & 0 & 0 & 0 & $19(2.7)$ \\
\hline Colorectal & 19.3 & $|2|(7.8)$ & $29(9.0)$ & 37 (1 I.5) & $7(18.4)$ & $2(25.0)$ & I (50) & $76(11.0)$ \\
\hline Renal & 18.2 & $27(1.7)$ & $6(1.9)$ & $9(2.8)$ & 0 & 0 & 0 & $15(2.2)$ \\
\hline Lymphoma & 16.7 & $100(6.5)$ & $20(6.2)$ & $19(5.9)$ & $3(7.9)$ & 0 & 0 & $42(6.1)$ \\
\hline CLL & 16.7 & 45 (2.9) & $9(2.8)$ & $16(5.0)$ & I (2.6) & 0 & 0 & $26(3.8)$ \\
\hline Breast & 14.3 & $563(36.3)$ & $94(29.2)$ & $59(18.3)$ & $3(7.9)$ & 0 & 0 & $156(22.5)$ \\
\hline Oral-pharynx & 10.5 & $34(2.2)$ & $4(1.2)$ & $4(1.2)$ & $2(5.3)$ & 0 & 0 & $10(1.4)$ \\
\hline Myeloma & 7.7 & $36(2.3)$ & $3(0.9)$ & $12(3.7)$ & $2(5.3)$ & $2(25.0)$ & 0 & $19(2.7)$ \\
\hline Esophagus & 6.7 & $28(1.8)$ & $2(0.6)$ & $7(2.2)$ & I (2.6) & 0 & 0 & $10(1.4)$ \\
\hline Lung & 5.6 & $219(14.1)$ & $13(4.0)$ & $58(18.0)$ & $6(15.8)$ & 0 & 0 & 77 (II.I) \\
\hline Acute leukemia & 3.4 & $28(1.8)$ & I $(0.3)$ & $3(0.9)$ & I (2.6) & 0 & 0 & $5(0.7)$ \\
\hline Pancreas & 0 & $34(2.2)$ & 0 & $9(2.8)$ & I (2.6) & 0 & 0 & $10(1.4)$ \\
\hline Gallbladder & 0 & $9(0.6)$ & 0 & $5(1.6)$ & 0 & 0 & 0 & $5(0.7)$ \\
\hline Liver & 0 & $9(0.6)$ & 0 & $2(0.6)$ & 0 & 0 & 0 & $2(0.3)$ \\
\hline Others & & $105(6.8)$ & $13(4.0)$ & $26(8.1)$ & $3(7.9)$ & I (I2.5) & I (50) & $44(6.4)$ \\
\hline \multicolumn{9}{|l|}{ Initial stage } \\
\hline Patients (n) & & $|, 55|$ & 322 & 322 & 38 & 8 & 2 & 692 \\
\hline Stage 0 & 22.6 & $4 \mid(2.6)$ & $12(3.7)$ & $19(5.9)$ & $7(18.4)$ & $4(50)$ & 0 & $42(6.1)$ \\
\hline Stage I & 29.4 & $336(21.7)$ & $140(43.5)$ & $98(30.4)$ & I5 (39.5) & $3(37.5)$ & I (50) & 257 (37.I) \\
\hline Stage II & 19.8 & $413(26.6)$ & $102(3 \mid .7)$ & $72(22.4)$ & $6(15.8)$ & 0 & 0 & $180(26.0)$ \\
\hline Stage III & 9.8 & $333(2 \mid .5)$ & $36(11.2)$ & $48(14.9)$ & $4(10.5)$ & 0 & 0 & 88 (I2.7) \\
\hline Stage IV & 7.0 & $428(27.6)$ & $32(9.9)$ & $85(26.4)$ & $6(15.8)$ & I (I2.5) & I (50) & $125(18.1)$ \\
\hline
\end{tabular}

Abbreviation: CLL, chronic lymphocytic leukemia.

publications may be related to the increased awareness of the possibility of second malignancies, the frequent use and increased sensitivity of screening procedures during follow-up, and better treatment delivered to the initial malignancy, with improved survival. ${ }^{22}$ This was evident in the present study, where proactive screening for second primaries led to detection of $24(1.3 \%)$ patients with asymptomatic stage 0 second malignancies.

\section{Possible risk factors}

Development of multiple primaries in cancer survivors may be related to increased awareness or be secondary to previous therapies, and may also be due to shared risk factors, including environment, lifestyle, and inherited genes. ${ }^{14}$

Age is considered to be a risk factor. The prevalence of multiple neoplasms was reported to be $5 \%-12 \%$ for patients aged 50-64 years, compared with $12 \%-26 \%$ for those aged over 80 years..$^{22}$ In the present study, the highest incidence was seen among those aged 60-69 years. However, the differences were not statistically significant.

Ethnic background is an important risk factor. Different societies have more prevalent tumors than others. For example, the high incidence of gastric cancer but low incidence of prostate cancer in Japan is in marked contrast with the US population. ${ }^{25}$ In the present study, patients of Caucasian ancestry had higher incidences of multiple primaries compared with other ethnic groups, even though the differences were relatively small, being about $10 \%$ above the overall cohort. In a previous report on the same group of patients, those with Caucasian ancestry were more liable to develop vascular thrombosis, with a higher cumulative incidence of multiple thrombophilic gene mutations ${ }^{26}$ (Table 5). 
Table 5 Demographic data and tumor characteristics for all patients based on ethnicity

\begin{tabular}{|c|c|c|c|c|}
\hline Demographic data & $\begin{array}{l}\text { Caucasians } \\
\text { n (\%) }\end{array}$ & $\begin{array}{l}\text { Others } \\
\text { n (\%) }\end{array}$ & $P$-value & $\begin{array}{l}\text { Total } \\
\text { n (\%) }\end{array}$ \\
\hline Patients (n) & $|, 48|$ & 310 & & $|, 79|$ \\
\hline \multicolumn{5}{|l|}{ Age at diagnosis } \\
\hline$\leq 64$ years & 785 (53.0\%) & $228(73.6 \%)$ & 0.00000 & $\mathrm{I}, 0 \mathrm{I} 3(56.6 \%)$ \\
\hline$>65$ years & $696(47.0 \%)$ & $82(26.5 \%)$ & & 778 (43.4\%) \\
\hline \multicolumn{5}{|l|}{ Sex } \\
\hline Male & $642(43.4 \%)$ & $56(18.1 \%)$ & 0.00000 & $698(39.0 \%)$ \\
\hline Female & $839(56.7 \%)$ & $254(81.9 \%)$ & & $\mathrm{I}, 093(61.0 \%)$ \\
\hline \multicolumn{5}{|l|}{ Body BMI } \\
\hline Underweight & 59 (4.7\%) & $6(2.2 \%)$ & 0.00017 & 65 (4.2\%) \\
\hline Normal BMI & $412(32.4 \%)$ & $58(21.6 \%)$ & & $470(30.6 \%)$ \\
\hline Overweight & 799 (62.9\%) & 204 (76.1\%) & & $1,003(65.2 \%)$ \\
\hline \multicolumn{5}{|l|}{ Atherosclerosis } \\
\hline Absent & 902 (60.9\%) & 225 (72.6\%) & 0.00011 & I,I 27 (62.9\%) \\
\hline Present & $579(39.1 \%)$ & 85 (27.4\%) & & $664(37.1 \%)$ \\
\hline \multicolumn{5}{|l|}{ Smoking } \\
\hline Nonsmoker & $585(41.5 \%)$ & $125(42.4 \%)$ & 0.77953 & $710(41.6 \%)$ \\
\hline Smoker & $825(58.5 \%)$ & $170(57.6 \%)$ & & 995 (58.4\%) \\
\hline \multicolumn{5}{|l|}{ Thrombosis } \\
\hline Absent & I,222 (82.5\%) & 275 (88.7\%) & 0.00739 & I,497 (83.5\%) \\
\hline Present & $259(17.5 \%)$ & $35(11.3 \%)$ & & $294(16.4 \%)$ \\
\hline \multicolumn{5}{|l|}{ Thrombophilic genes } \\
\hline Normal genes & 14 (I5.6\%) & $4(80.0 \%)$ & 0.00450 & $18(18.9 \%)$ \\
\hline One gene mutation & 38 (42.2\%) & I (20.0\%) & & 39 (4I.I\%) \\
\hline Two gene mutations & 34 (37.8\%) & 0 & & 34 (35.8\%) \\
\hline Three/more gene mutations & $4(4.4 \%)$ & 0 & & $4(4.2 \%)$ \\
\hline \multicolumn{5}{|l|}{ Handedness } \\
\hline Right-handed & I7I (93.5\%) & $100(92.6 \%)$ & 0.66821 & $272(93.2 \%)$ \\
\hline Not right-handed & $12(6.5 \%)$ & $8(7.4 \%)$ & & $20(6.8 \%)$ \\
\hline \multicolumn{5}{|l|}{ Family history of cancer } \\
\hline Strong family history & $190(16.8 \%)$ & 71 (26.4\%) & $0.0034 I$ & $26 \mid(18.6 \%)$ \\
\hline Intermediate family history & $595(52.6 \%)$ & $123(45.7 \%)$ & & $718(51.3 \%)$ \\
\hline Weak family history & $152(13.4 \%)$ & $36(13.4 \%)$ & & $188(13.4 \%)$ \\
\hline No family history of cancer & 194 (I7.2\%) & 39 (I4.5\%) & & $233(16.6 \%)$ \\
\hline \multicolumn{5}{|l|}{ Initial primary site } \\
\hline Breast & $412(27.8 \%)$ & $212(68.4 \%)$ & 0.0000 & $624(34.8 \%)$ \\
\hline Lung & $199(13.4 \%)$ & $22(7.1 \%)$ & & $221(12.3 \%)$ \\
\hline Genitourinary & $176(11.9 \%)$ & $9(2.9 \%)$ & & $185(10.3 \%)$ \\
\hline Gastrointestinal & 149 (10.1\%) & $8(2.6 \%)$ & & 157 (8.8\%) \\
\hline Hematologic & II 4 (7.7\%) & $13(4.2 \%)$ & & $127(7.1 \%)$ \\
\hline Gynecologic & $106(7.2 \%)$ & 14 (4.5\%) & & $120(6.7 \%)$ \\
\hline Lymphoma & $105(7.1 \%)$ & $10(3.2 \%)$ & & 115 (6.4\%) \\
\hline Head and neck & $74(5.0 \%)$ & $4(1.3 \%)$ & & $78(4.4 \%)$ \\
\hline Hepatobiliary & $43(2.9 \%)$ & $7(2.3 \%)$ & & $50(2.8 \%)$ \\
\hline Dermatologic & $48(3.2 \%)$ & I $(0.3 \%)$ & & $49(2.7 \%)$ \\
\hline Others & 55 (3.7\%) & $10(3.2 \%)$ & & $65(3.6 \%)$ \\
\hline \multicolumn{5}{|l|}{ Multiple primaries } \\
\hline Single primary & I, 197 (80.8\%) & $282(91.0 \%)$ & 0.00002 & I,479 (82.6\%) \\
\hline Multiple primaries & $284(19.2 \%)$ & $28(9.0 \%)$ & & $312(17.4 \%)$ \\
\hline \multicolumn{5}{|l|}{ Initial cancer stage } \\
\hline Stage $0 / I / I I$ & $802(54.2 \%)$ & 198 (63.9\%) & 0.00173 & $\mathrm{I}, 000(55.8 \%)$ \\
\hline Stage III/IV & $679(45.9 \%)$ & $112(36.1 \%)$ & & 791 (44.2\%) \\
\hline \multicolumn{5}{|l|}{ Tumor multicentricity } \\
\hline Unifocal & I,052 (77.3\%) & $212(73.9 \%)$ & 0.21182 & I,264 (76.7\%) \\
\hline Multifocal & $309(22.7 \%)$ & 75 (26.1\%) & & $384(23.3 \%)$ \\
\hline \multicolumn{5}{|l|}{ Survival from diagnosis, years } \\
\hline Mean \pm SD & $6.90( \pm 8.05)$ & $4.94( \pm 5.59)$ & 0.00004 & \\
\hline
\end{tabular}

Abbreviations: BMI, body mass index; SD, standard deviation. 


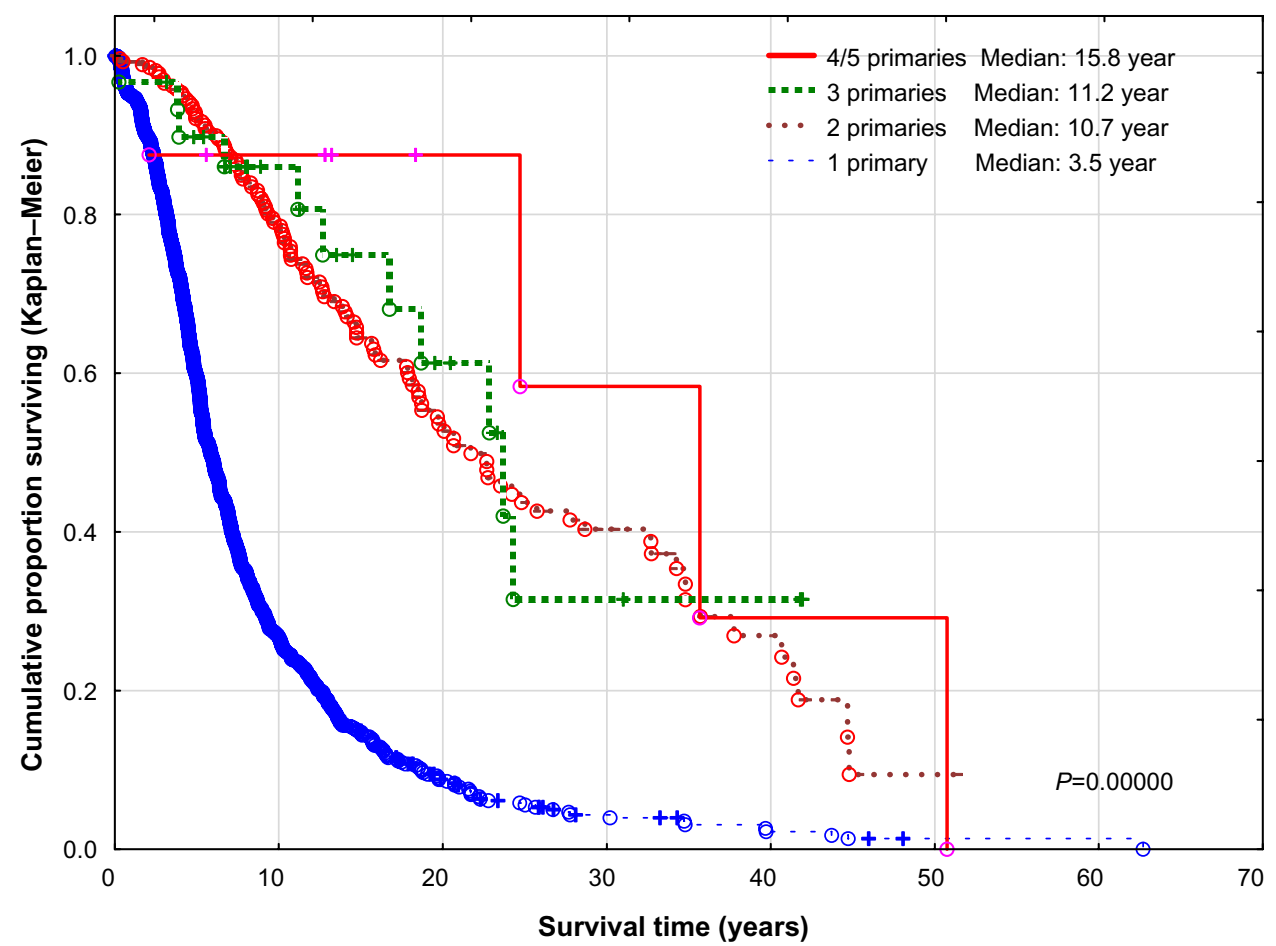

Figure I Survival of patients with single and multiple cancer primaries. Differences for all groups as well as differences between single and two primaries were highly statistically significant $(P=0.0000)$. However, there was no difference between two and three primaries $(P=0.744 \mathrm{I})$ or between three and four primaries $(P=0.54408)$.

Hence the possibility of other genetic factors may contribute to the development of multiple malignancies in the Caucasian population.

Obesity has been linked with the occurrence of cancer in the general population, particularly that of the breast, female reproductive organs, and the gastrointestinal tract. ${ }^{22}$ Obesity has also been reported to increase the risk of second primary cancer, particularly endometrial and colon cancers. ${ }^{27,28}$ This was not detected in the present study, with obesity being seen more frequently in patients with single primaries than in those

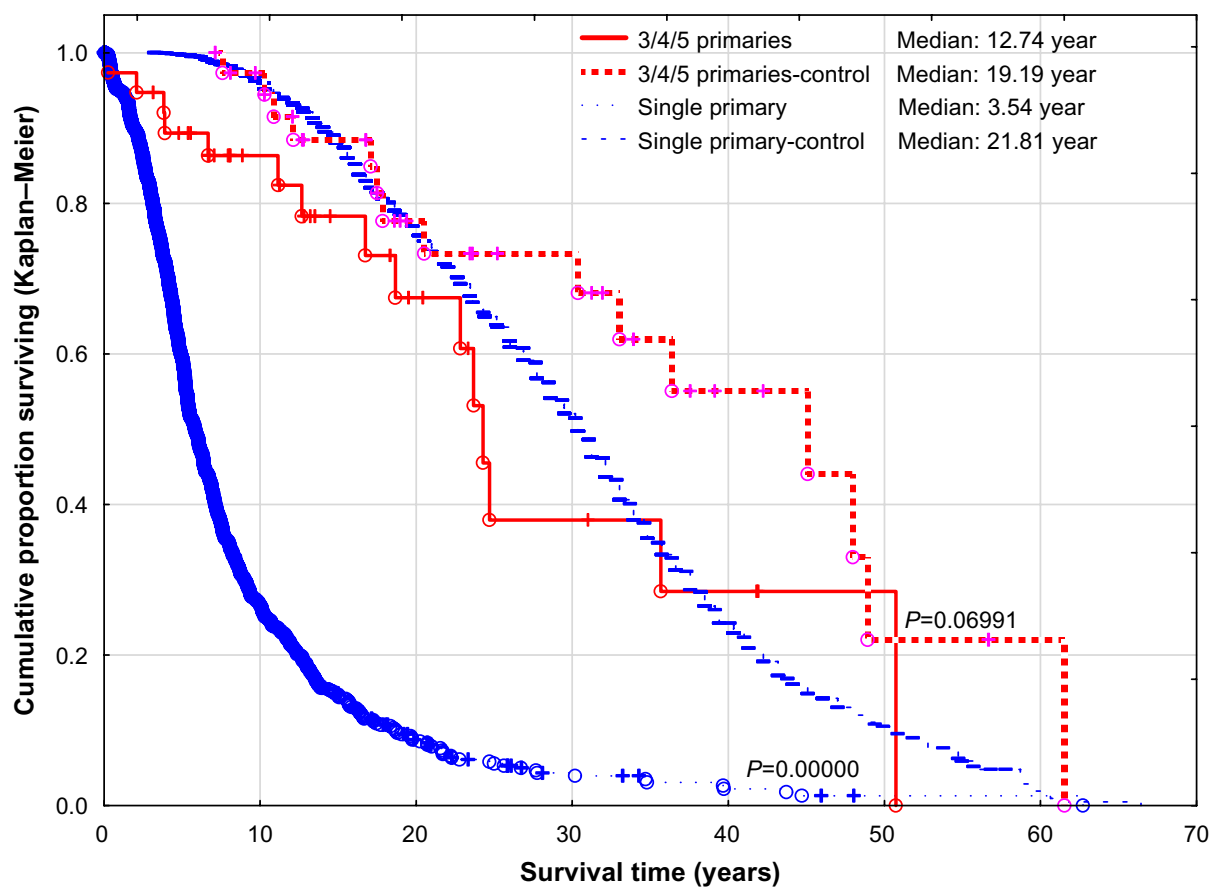

Figure 2 Survival of cancer patients with a single primary and multiple primaries versus matched controls. 


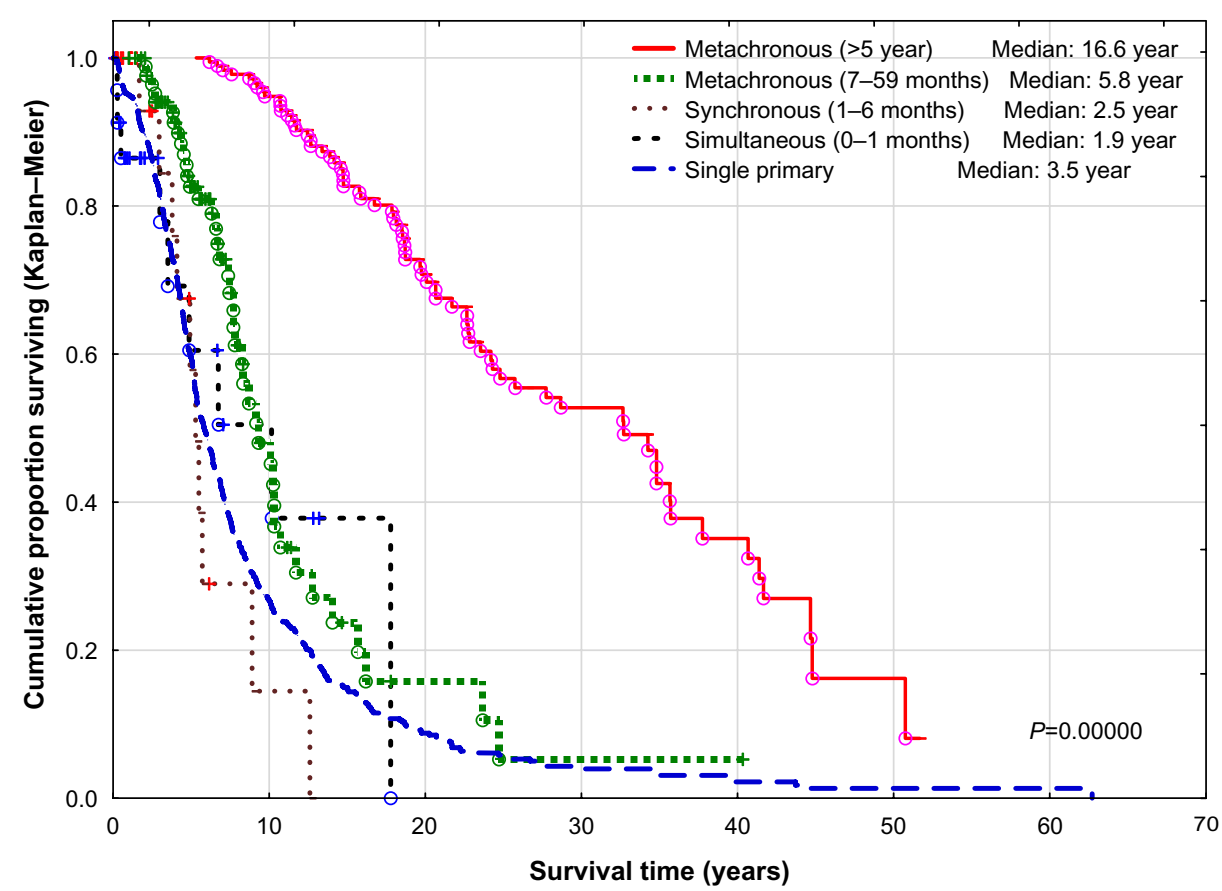

Figure 3 Survival of cancer patients with single, simultaneous, synchronous, and metachronous primaries. Differences between single primary and metachronous less than 5 years and between metachronous less than 5 years and metachronous more than 5 years were highly statistically significant $(P=0.0000)$. However, there was no difference between single primary versus simultaneous primaries and synchronous primaries $(P=0.97947)$.

with multiple primaries. This lack of correlation may possibly be due to the small number of patients studied.

Smoking-related second malignancies account for 35\% of the subsequent cancer cases observed in US cancer survivors. ${ }^{22}$ A consistent excess of primary smoking-related cancers such as those of the oral cavity, pharynx, larynx, lung, and bladder have been reported in patients previously diagnosed with similar malignancies. ${ }^{22}$ It has been reported that interindividual variation in DNA repair capacity may lead to increased predisposition to cancer. ${ }^{29}$ Abnormal mutagen

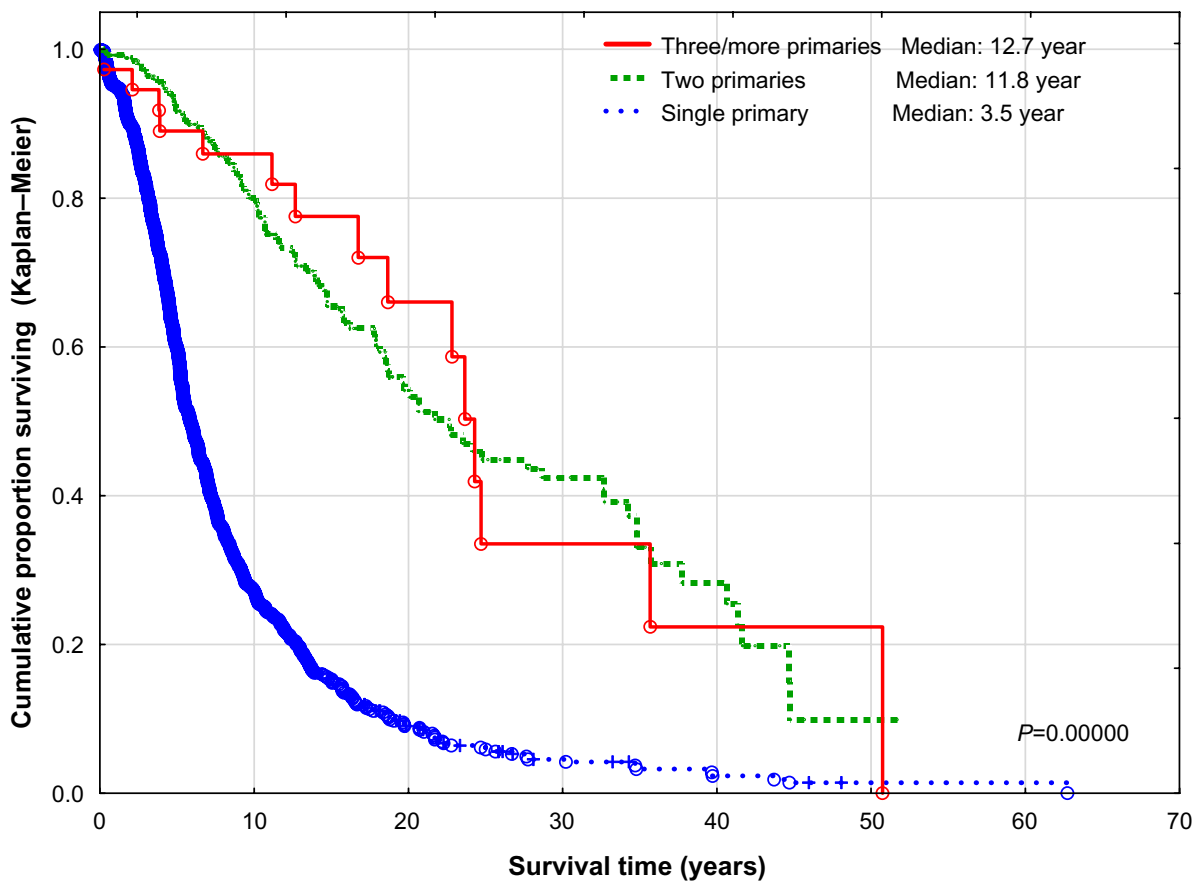

Figure 4 Survival of patients with single and multiple primary invasive cancers. Differences between single and two primaries were highly statistically significant $(P=0.0000)$. However, there was no difference between two primaries and three or more primaries $(P=0.70173)$. 


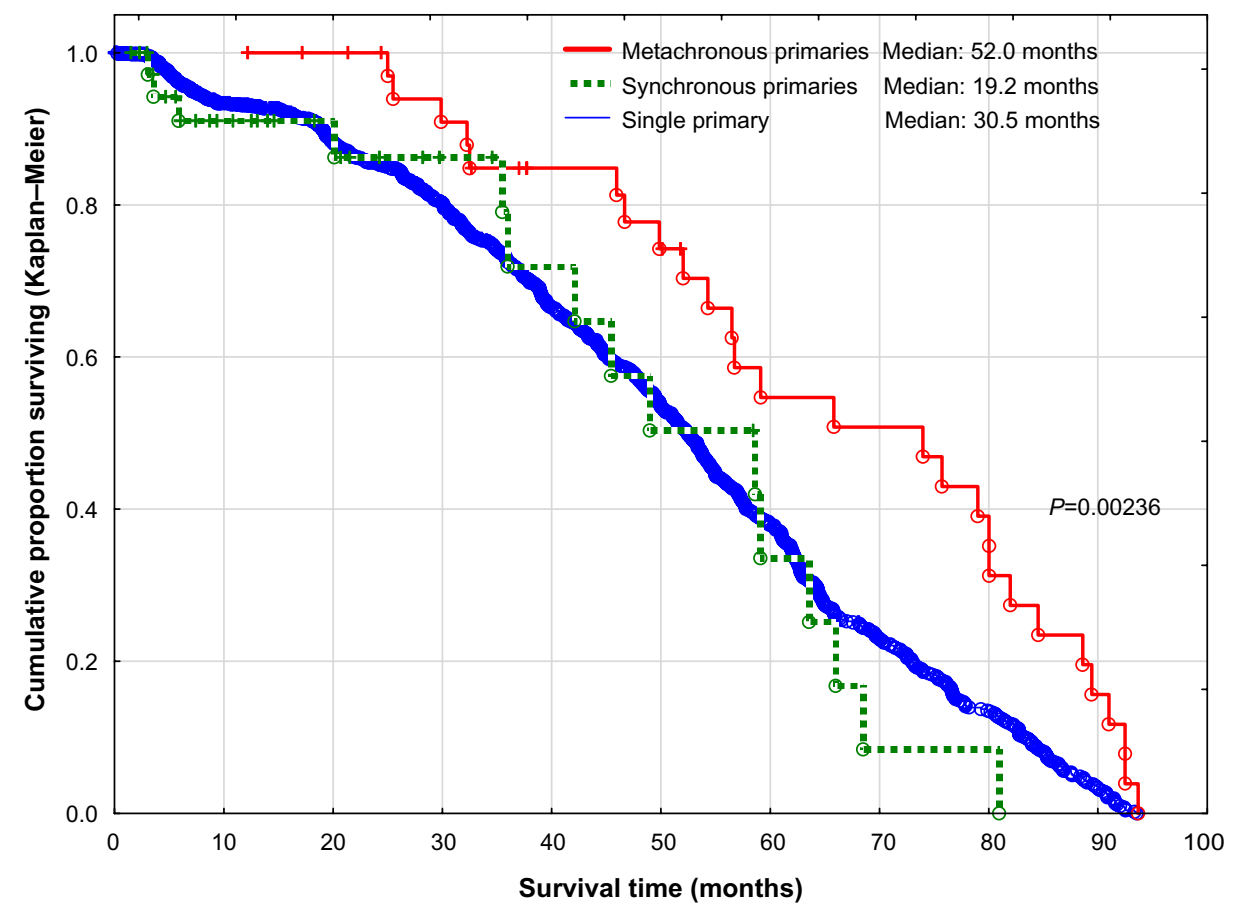

Figure 5 Survival of cancer patients with single, synchronous, and metachronous primaries seen between 2005 and 2012 . The differences for all groups ( $P=0.00236)$ as well as between single primary and metachronous primaries $(P=0.00052)$ were statistically significant. However, there was no difference between single primary and synchronous primaries $(P=0.88344)$.

sensitivity found in studies that indirectly assessed DNA repair capacity has been found in patients with head and neck, colorectal, and non-small-cell lung cancers, as well as in patients with multiple primaries of similar malignancies. ${ }^{30} \mathrm{In}$ the present analysis, cancer survivors who were smokers had a higher risk of multiple primaries compared with nonsmokers, particularly for lung, colorectal, and prostate cancers.

Women whose first primary is the breast account for $25 \%$ of survivors with multiple cancers, followed by colorectal cancer $(15 \%)$ as the first primary in both men and women,

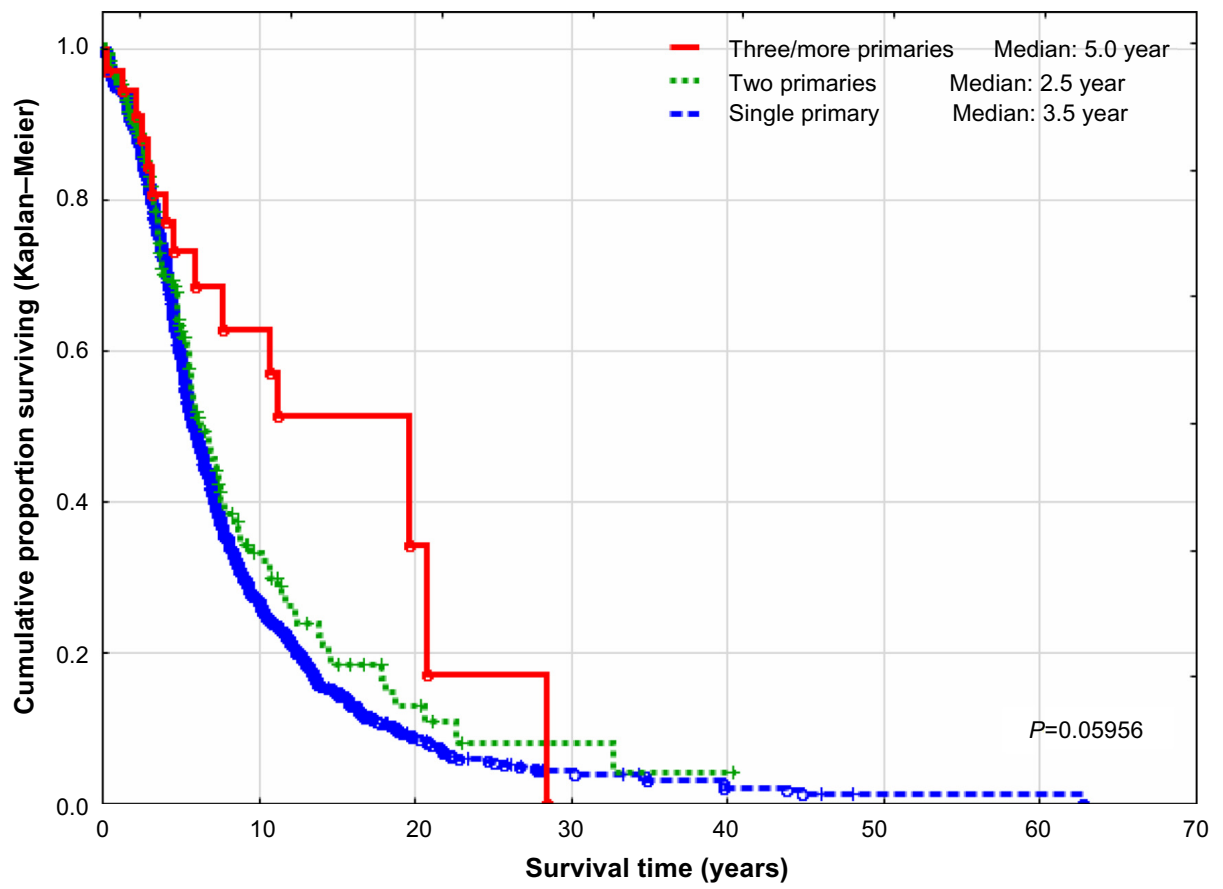

Figure 6 Survival of patients with single and multiple cancer primaries calculated from date of diagnosis of second primary for patients with multiple cancers. 


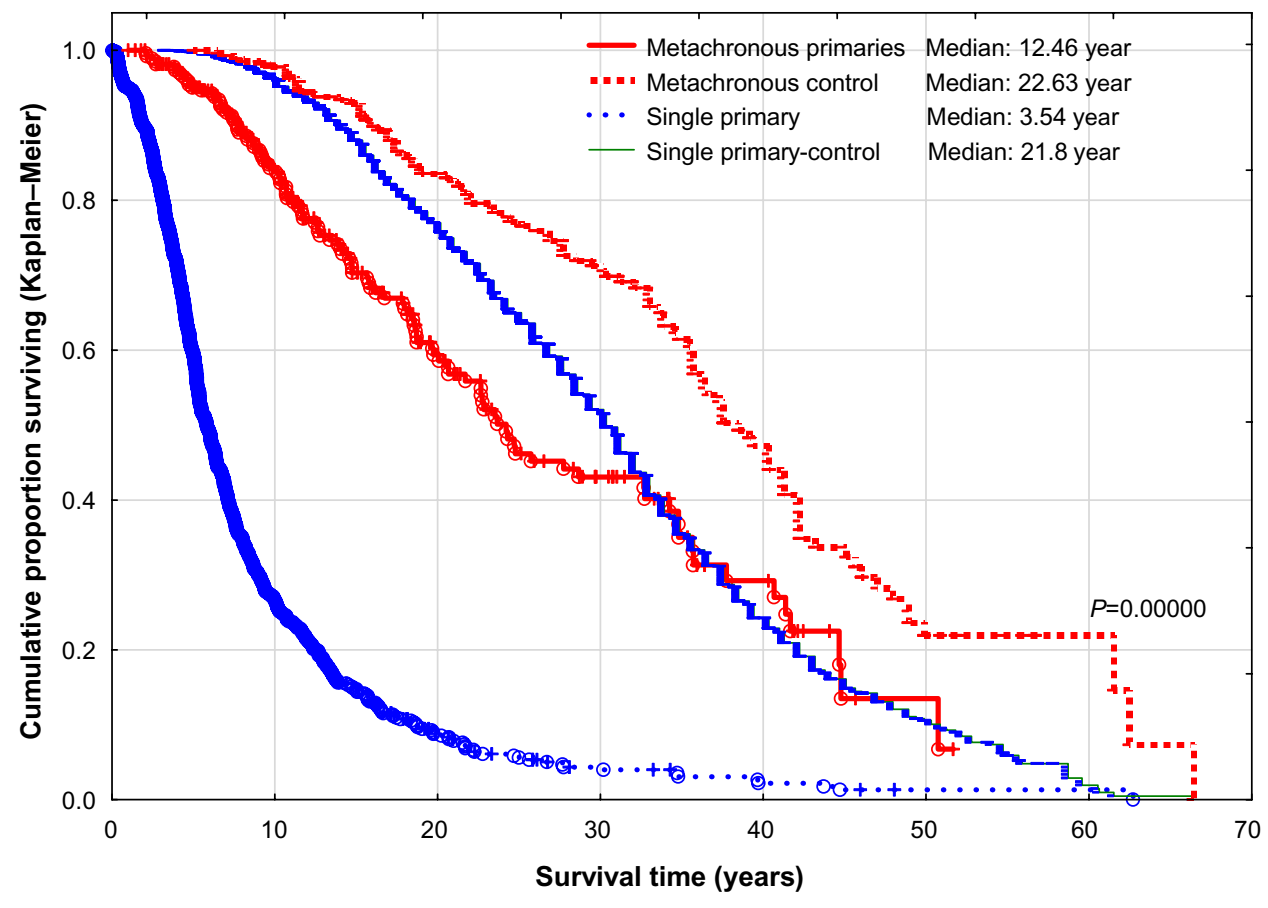

Figure 7 Survival of patients with single and metachronous primaries compared with a matched control group.

according to SEER data. ${ }^{2}$ In the present study, the most common initial primary among cancer survivors with multiple primaries for both men and women was breast, prostate, and colorectal. Patients who initially presented with thyroid, urinary bladder, prostate, cervical, and uterine cancers were more liable to develop a second malignancy, while those with hepatic, biliary tract, and pancreatic cancers as well as those with acute leukemia rarely developed a second malignancy. This may be related to the poor outcome in these patients, who did not survive long enough to develop second primaries.

Patients with multiple primaries usually present initially with tumors at lower stages than secondary primaries. ${ }^{22,31-33} \mathrm{In}$ the present study, initial index primaries were predominantly at an earlier stage (78.8\%), compared with second primaries (47\%). Considering all cancer patients, the risk of developing multiple primaries was much higher for those presenting initially with stage 0 or stage I disease. This finding may be also related to the shorter survival time of patients initially presenting with advanced disease.

The etiologic role of cancer therapy in the development of second malignancies has been described extensively by others. ${ }^{34}$ Second primaries following chemotherapy usually arise within a few months to 9 years, while after radiation therapy or hormonal treatment, chronic sequelae usually develop after a longer latency period of 5-10 years. ${ }^{22}$ However, many believe that a second primary may not be attributed solely to prior treatment. It is most likely a combination of risk factors, such as genetic predisposition, lifestyle, and environmental influence, and could even be a behavioral effect. ${ }^{7,9,22}$

Family history is an important risk factor for multiple primary neoplasms. Almost all cancer sites showed an excess of familial clustering, and most of the evidence has been based on excess of close relationship among cases related to families of of 3 to 15 generations deep. ${ }^{35}$ Practically all types of hereditary cancers showed an excess of multiple primaries as well as an early age of onset. ${ }^{22,24,27,28,31-33,36}$ It has been suggested that abnormal genes or gene variants might be responsible for the clustering observed with some tumors. Multiple cancer predisposition genes have already been identified in high-risk pedigrees such as $B R C A 1, B R C A 2$, and $p 16 / C D K N 2 A .^{22,35}$ Individuals with hereditary nonpolyposis colorectal cancer with multiple primaries have an increased frequency of mismatch repair genes, such as $h M S H 2$ and $h M L H 1$, leading to microsatellite instability. ${ }^{33}$ Mutagen sensitivity, found in studies that indirectly assessed DNA repair capacity, tends to occur in patients with head and neck, hereditary nonpolyposis colorectal, and non-small-cell lung cancers. ${ }^{30}$ In the present study, a strong family history of cancer reflecting a close relationship between first-degree relatives was statistically more common in patients with multiple primaries, especially those with three or more primaries, and in those with metachronous primaries, highly suggestive of inherited cancer predisposition gene mutations, especially among Caucasian patients. 


\section{Impact on survival}

Survival of patients with multiple primaries varies widely in the literature, depending on the method of calculation, primary tumor site, cancer stage, year of initial cancer diagnosis, and time interval between index and second primaries.

Overall, patients with multiple primaries have a far better survival rate compared with those having a single primary. ${ }^{37}$ In the present analysis, a mean survival of 166 months versus 60 months was documented. In a study on oral and maxillofacial cancers at different sites, the mean survival was 127 months for patients with multiple primaries compared with 48 months for cases with a single primary $(P=0.001){ }^{5}$ However, when the survival of patients with the same cancer site was compared, calculated from the date of their respective primary diagnosis, there were no statistically significant differences in survival between those who had one primary and those who had more than one primary. ${ }^{5}$ Calculating survival from the date of the second primary has been used in several reports comparing multiple primaries with single ones, with no differences in survival ${ }^{37,38}$ or an even worse prognosis for patients with multiple primaries. ${ }^{3,4}$ In the present analysis, using a similar method of calculation, the survival of patients who developed second malignancies was relatively similar to single primary. Thus, the improved survival of patients with multiple primaries may be a reflection of different patient populations having a dissimilar pattern of initial tumor sites (predominantly favorable ones) and/or stages of disease (mainly earlier ones), rather than tumor multiplicity.

As a rule, the more time that elapses between the first primary malignancy and a second malignancy, the better the prognosis. ${ }^{5}$ Most studies have shown that patients with synchronous primaries have a poor prognosis compared with those having metachronous primaries. ${ }^{5,39}$ In one study, the 5 -year survival rate was $18 \%$ compared with $55 \%$, respectively. ${ }^{19}$ In the present analysis, the 5-year survival of patients with a single primary was $59 \%$, compared with those having simultaneous (61\%), synchronous (59\%), and metachronous primaries (95\%). Overall, patients initially presenting with two primaries, either simultaneously or within 6 months of each other, have a similar survival to those with a single primary, and the more time that elapses from the first index primary to the second primary, the better the survival, especially if the interval exceeds 5 years.

Survival of patients with multiple primaries also depends on the site of the second primary. For breast cancer, the best survival was noted for metachronous contralateral breast cancer when the second cancer was diagnosed at least 5 years after the original primary, with 5-year and 10-year survival rates of $100 \%$ and $96 \%$, respectively. ${ }^{37}$ For lung cancer as a second primary, the 5-year survival for those with a metachronous primary was $44 \%$ compared with $10 \%$ for those with a synchronous primary ${ }^{39}$ With hepatocellular cancer, there were no significant differences in survival, whether presenting as a single primary or as a second primary following another malignancy, ${ }^{38}$ but not as a synchronous primary concomitantly diagnosed with another cancer, which carries the worst prognosis. ${ }^{40}$

Most reports on patients with multiple primaries include patients at an earlier stage 0 (carcinoma in situ), while others limit the study to invasive cancers (stage I and above). ${ }^{41}$ Inclusion of stage 0 in survival analysis usually results in a favorable survival outcome. In the present analysis, the improved survival of patients with multiple malignancies persists regardless of whether or not stage 0 patients are included.

Most studies on multiple primaries report on patients seen at certain intervals based on the year of initial cancer diagnosis, while others report on groups of patients seen at a specific period of time, irrespective of the date of initial cancer diagnosis. The latter method has a risk of bias, by including patients with favorable cancers who live long enough to be included in the analysis. The present analysis included all consecutive patients seen during a specific period, irrespective of the date of initial cancer diagnosis. However, analysis of patients initially diagnosed between 2005 and 2012 confirmed the same findings, ie, improved survival for cases with multiple primaries, and especially for metachronous ones.

\section{Study limitations}

This study, being a retrospective analysis of a limited number of patients, has several limitations. It explores outcomes in a heterogeneous group of patients at different stages of malignancy who have received various types of therapies. The reported incidence of multiple primaries may be underestimated because the duration of follow-up for some patients was relatively short, and a longer follow-up, logically, will reveal development of more second primaries. Further, exclusion of patients with skin cancers as well as those with carcinoma in situ of the uterine cervix may also have underestimated the overall incidence of multiple neoplasms. In addition, considering the variation seen in the incidence of multiple primaries between patients of different ethnic background, our findings may not necessarily be applicable to other populations of different ethnic composition. Consequently, unexpected bias may exist.

However, the study does have significance despite these limitations. Its main strength is the inclusion of all patients 
seen and followed closely in a single-practice, real-world situation that provides a representative picture of cancer patients in general. It defines the relative incidence and subtypes of multiple primaries among cancer patients of various ethnic groups as well as their impact on survival. It showed relatively consistent results, whether cancer was inclusive of all subtypes or limited to a certain stage of disease, and whether the study population was initially diagnosed over several decades or limited to a defined period of time.

\section{Conclusion}

In conclusion, patients with multiple primaries are usually of Caucasian ancestry, have less aggressive malignancies, present at earlier stages of disease, and frequently have a strong family history of similar malignancies. They tend to have cancers with indolent clinical behavior and longer overall survival, especially in those developing second malignancies more than 5 years after the initial primary diagnosis. For patients with three or more primaries, their survival has been similar to the projected life expectancy of the age-matched and sex matched normal population, even though they were treated less aggressively. The development of multiple primaries may possibly be related to genetic disorders of known or an unidentified nature. The higher frequency of cancer predisposition genes in Caucasians may well explain this increased frequency of multiple primaries. The possibility of multiple primary malignancies should always be considered during the treatment and follow-up of cancer patients, especially those of Caucasian ancestry and those having a strong family history of cancer. Due to the potential for long-term survival, more aggressive treatment may be warranted. For elderly and relatively asymptomatic cases having more than three primaries, a less aggressive approach to therapy may be adequate.

\section{Acknowledgments}

The author thanks Joseph Anigbogu, Kemi Azeez, Pratap Balusu, Glenn Bryant, Sreenivasa Chanamolu, Henry Gerad, Ravi Kamepalli, Abbas Khalil, Sarat Kuchipudi, Chaoyang Li, Oluremi Ojo, David Powell, and Abdullah Taja for patient referrals.

\section{Disclosure}

The author reports no conflicts of interest in this work.

\section{References}

1. Gursel B, Meydan D, Ozbek N, Ozdemir O, Odabas E. Multiple primary malignant neoplasms from the black sea region of Turkey. J Int Med Res. 2011;39(2):667-674.
2. Mariotto AB, Rowland JH, Ries LA, Scoppa S, Feuer EJ. Multiple cancer prevalence: a growing challenge in long-term survivorship. Cancer Epidemiol Biomarkers Prev. 2007;16(3):566-571.

3. Soerjomataram I, Louwman WJ, de Vries E, Lemmens VE, Klokman WJ, Coebergh JW. Primary malignancy after primary female breast cancer in the South of The Netherlands, 1972-2001. Breast Cancer Res Treat. 2005;93(1):91-95.

4. Rosso S, De Angelis R, Ciccolallo L, et al. Multiple tumours in survival estimates. Eur J Cancer. 2009;45(6):1080-1094.

5. Friedrich RE. Primary and second primary cancer in 649 patients with malignancies of the maxillofacial region. Anticancer Res. 2007;27(4A): $1805-1818$.

6. Tabuchi T, Ito Y, Ioka A, Miyashiro I, Tsukuma H. Incidence of metachronous second primary cancers in Osaka, Japan: update of analyses using population-based cancer registry data. Cancer Sci. 2012;103(6):1111-1120.

7. Thomas A, Mailankody S, Korde N, Kristinsson SY, Turesson I, Landgren O. Second malignancies after multiple myeloma: from 1960s to 2010s. Blood. 2012;119(12):2731-2737.

8. Liu L, de Vries E, Louwman M, et al. Prevalence of multiple malignancies in The Netherlands in 2007. Int J Cancer. 2011;128(7):1659-1667.

9. Travis LB, Rabkin CS, Brown LM, et al. Cancer survivorship - genetic susceptibility and second primary cancers: research strategies and recommendations. J Natl Cancer Inst. 2006;98(1):15-25.

10. Pages PB, Mordant P, Grand B, et al. History of multiple previous malignancies should not be a contraindication to the surgical resection of lung cancer. Ann Thorac Surg. 2013;95(3):1000-1005.

11. Bordin GM, Key CR, McQuade CE, Kutvirt DM, Hughes WB, Brylinski DA. Multiple primary cancers: relative risk in New Mexico's triethnic population. Cancer. 1977;40(Suppl 4):1793-1800.

12. Hajdu SI, Hajdu EO. Multiple primary malignant tumors. J Am Geriatr Soc. 1968;16(1):16-26.

13. Haddow AJ, Boyd JF. Multiple primary neoplasms in the Western Hospital Region, Scotland: a survey based on cancer registration data. Scott Med J. 1972;17(4):143-152.

14. Rosso S, Terracini L, Ricceri F, Zanetti R. Multiple primary tumours: incidence estimation in the presence of competing risks. Popul Health Metr. 2009;7:5.

15. Berge T, Cederqvist L, Schonebeck J. Multiple primary malignant tumours. An autopsy study of a circumscribed population. Acta Pathol Microbiol Scand. 1969;76(2):171-183.

16. Salem A, Abu-Hijlih R, Abdelrahman F, et al. Multiple primary malignancies: analysis of 23 patients with at least three tumors. J Gastrointest Cancer. 2012;43(3):437-443.

17. Watanabe $\mathrm{S}$, Kodama $\mathrm{T}$, Shimosato $\mathrm{Y}$, et al. Multiple primary cancers in 5,456 autopsy cases in the National Cancer Center of Japan. $J$ Natl Cancer Inst. 1984;72(5):1021-1027.

18. Lee TK, Myers RT, Scharyj M, Marshall RB. Multiple primary malignant tumors (MPMT): study of 68 autopsy cases (1963-1980). J Am Geriatr Soc. 1982;30(12):744-753.

19. Panosetti E, Luboinski B, Mamelle G, Richard JM. Multiple synchronous and metachronous cancers of the upper aerodigestive tract: a nine-year study. Laryngoscope. 1989;99(12):1267-1273.

20. Weir HK, Johnson CJ, Thompson TD. The effect of multiple primary rules on population-based cancer survival. Cancer Causes Control. 2013;24(6):1231-1242.

21. Sankila R, Pukkala E, Teppo L. Risk of subsequent malignant neoplasms among 470,000 cancer patients in Finland, 1953-1991. Int J Cancer. 1995;60(4):464-470.

22. Soerjomataram I, Coebergh JW. Epidemiology of multiple primary cancers. Methods Mol Biol. 2009;471:85-105.

23. Armstrong GT, Liu W, Leisenring W, et al. Occurrence of multiple subsequent neoplasms in long-term survivors of childhood cancer: a report from the childhood cancer survivor study. J Clin Oncol. 2011;29(22):3056-3064.

24. Lynch HT, Harris RE, Lynch PM, Guirgis HA, Lynch JF, Bardawil WA. Role of heredity in multiple primary cancer. Cancer. 1977; 40(Suppl 4):1849-1854. 
25. Tomoda H, Taketomi A, Baba H, Kohnoe S, Seo Y, Saito T. Multiple primary colorectal and gastric carcinoma in Japan. Oncol Rep. 1998;5(1):147-149.

26. Amer MH. Cancer-associated thrombosis: clinical presentation and survival. Cancer Manag Research. 2013;5:165-178.

27. Trentham-Dietz A, Newcomb PA, Nichols HB, Hampton JM. Breast cancer risk factors and second primary malignancies among women with breast cancer. Breast Cancer Res Treat. 2007;105(2):195-207.

28. Kmet LM, Cook LS, Weiss NS, Schwartz SM, White E. Risk factors for colorectal cancer following breast cancer. Breast Cancer Res Treat. 2003;79(2):143-147.

29. Hussain T, Kotnis A, Sarin R, Mulherkar R. Genetic susceptibility to multiple primary neoplasms in the upper aero-digestive tract: genotype score and phenotype correlation. Cancer Lett. 2013;332(1):46-54.

30. Orlow I, Park BJ, Mujumdar U, et al. DNA damage and repair capacity in patients with lung cancer: prediction of multiple primary tumors. J Clin Oncol. 2008;26(21):3560-3566.

31. Hisada M, Garber JE, Fung CY, Fraumeni JF Jr, Li FP. Multiple primary cancers in families with Li-Fraumeni syndrome. J Natl Cancer Inst. 1998;90(8):606-611.

32. Hemminki K, Li X. Familial risk for lung cancer by histology and age of onset: evidence for recessive inheritance. Exp Lung Res. 2005;31(2):205-215.

33. Artac M, Bozcuk H, Ozdogan M, et al. Different clinical features of primary and secondary tumors in patients with multiple malignancies. Tumori. 2005;91(4):317-320.
34. Dimopoulos MA, Richardson PG, Brandenburg N, et al. A review of second primary malignancy in patients with relapsed or refractory multiple myeloma treated with lenalidomide. Blood. 2012;119(12):2764-2767.

35. Albright F, Teerlink C, Werner TL, Cannon-Albright LA. Significant evidence for a heritable contribution to cancer predisposition: a review of cancer familiality by site. BMC Cancer. 2012;12:138.

36. Hill DA, Gilbert E, Dores GM, et al. Breast cancer risk following radiotherapy for Hodgkin lymphoma: modification by other risk factors. Blood. 2005;106(10):3358-3365.

37. Kollias J, Ellis IO, Elston CW, Blamey RW. Prognostic significance of synchronous and metachronous bilateral breast cancer. World J Surg. 2001;25(9):1117-1124.

38. Wong LL, Lurie F, Takanishi DM Jr. Other primary neoplasms in patients with hepatocellular cancer: prognostic implications? Hawaii Med J. 2007;66(8):204, 206-208.

39. Aziz TM, Saad RA, Glasser J, Jilaihawi AN, Prakash D. The management of second primary lung cancers. A single centre experience in 15 years. Eur J Cardiothorac Surg. 2002;21(3):527-533.

40. Zeng QA, Qiu J, Zou R, et al. Clinical features and outcome of multiple primary malignancies involving hepatocellular carcinoma: a long-term follow-up study. BMC Cancer. 2012;12:148.

41. Youlden DR, Baade PD. The relative risk of second primary cancers in Queensland, Australia: a retrospective cohort study. BMC Cancer. 2011;11:83.
Cancer Management and Research

\section{Publish your work in this journal}

Cancer Management and Research is an international, peer-reviewed open access journal focusing on cancer research and the optimal use of preventative and integrated treatment interventions to achieve improved outcomes, enhanced survival and quality of life for the cancer patient. The journal welcomes original research, clinical \& epidemiological

\section{Dovepress}

studies, reviews \& evaluations, guidelines, expert opinion \& commentary, case reports \& extended reports. The manuscript management system is completely online and includes a very quick and fair peerreview system, which is all easy to use. Visit http://www.dovepress.com/ testimonials.php to read real quotes from published authors. 